\title{
DRIVING INVESTMENTS TOWARD SUSTAINABLE ECONOMIC GROWTH IN THE PEOPLE'S REPUBLIC OF CHINA
}

Cameron Hepburn and Nicholas Stern

NO. 16

September 2019

\author{
ADB EAST ASIA \\ WORKING PAPER SERIES
}



ADB East Asia Working Paper Series

\section{Driving Investments Toward Sustainable Economic Growth in the People's Republic of China}

Cameron Hepburn and Nicholas Stern

No. 16 | September 2019
Cameron Hepburn is a Professor of the University of Oxford, and Nicholas Stern is an I G Patel Professor of the London School of Economics.

The authors thank Hannah McNicol of the Smith School of Enterprise and the Environment, Oxford and Isabella Neuweg of the Grantham Research Institute on Climate Change and the Environment, London School of Economics for their contributions to this paper. 
(C) 2019 Asian Development Bank

6 ADB Avenue, Mandaluyong City, 1550 Metro Manila, Philippines

Tel +632632 4444; Fax +6326362444

www.adb.org

Some rights reserved. Published in 2019.

Printed in the Philippines

Publication Stock No. WPS190459-2

DOI: http://dx.doi.org/10.22617/WPS190459-2

The views expressed in this publication are those of the authors and do not necessarily reflect the views and policies of the Asian Development Bank (ADB) or its Board of Governors or the governments they represent.

ADB does not guarantee the accuracy of the data included in this publication and accepts no responsibility for any consequence of their use. The mention of specific companies or products of manufacturers does not imply that they are endorsed or recommended by ADB in preference to others of a similar nature that are not mentioned.

By making any designation of or reference to a particular territory or geographic area, or by using the term "country" in this document, $A D B$ does not intend to make any judgments as to the legal or other status of any territory or area.

This work is available under the Creative Commons Attribution 3.0 IGO license (CC BY 3.0 IGO)

https://creativecommons.org/licenses/by/3.0/igo/. By using the content of this publication, you agree to be bound by the terms of this license. For attribution, translations, adaptations, and permissions, please read the provisions and terms of use at https://www.adb.org/terms-use\#openaccess.

This CC license does not apply to non-ADB copyright materials in this publication. If the material is attributed to another source, please contact the copyright owner or publisher of that source for permission to reproduce it. $\mathrm{ADB}$ cannot be held liable for any claims that arise as a result of your use of the material.

Please contact pubsmarketing@adb.org if you have questions or comments with respect to content, or if you wish to obtain copyright permission for your intended use that does not fall within these terms, or for permission to use the ADB logo.

Corrigenda to ADB publications may be found at http://www.adb.org/publications/corrigenda.

Notes:

In this publication, “\$” refers to United States dollars.

ADB recognizes "China" as the People's Republic of China.

The ADB East Asia Working Paper Series is a forum for stimulating discussion and eliciting feedback on ongoing and recently completed research and policy studies undertaken by the East Asia Department of the Asian Development Bank (ADB) staff, consultants, or resource persons. The series deals with key economic and development problems, as well as conceptual, analytical, or methodological issues relating to project/program economic analysis, and statistical data and measurement. The series aims to enhance the knowledge on Asia's development and policy challenges; strengthen analytical rigor and quality of ADB's country partnership strategies, and its subregional and country operations; and improve the quality and availability of statistical data and development indicators for monitoring development effectiveness.

The ADB East Asia Working Paper Series is a quick-disseminating, informal publication whose titles could subsequently be revised for publication as articles in professional journals or chapters in books. The series is maintained by the East Asia Department.

This paper was prepared as a background to the preparation of the High-Level Round Table Discussion on the People's Republic of China's transition to high-quality development, coordinated by the Asian Development Bank. 


\section{CONTENTS}

FIGURES

ACKNOWLEDGMENTS $\quad v$

ABSTRACT vi

ABBREVIATIONS vii

$\begin{array}{ll}\text { I. INTRODUCTION } & 1\end{array}$

II. $\quad$ STRATEGIC REFORMS FOR A NEW ERA 2

III. HIGH-QUALITY AND SUSTAINABLE GROWTH IN A CHANGING WORLD 3

IV. $\quad$ INVESTING IN THE FOUR CAPITALS TO DELIVER HIGH-QUALITY 6

SUSTAINABLE GROWTH: HUMAN, PHYSICAL, NATURAL, AND SOCIAL CAPITAL

A. Human Capital $\quad 7$

1. Human Capital and Sustainable Infrastructure $\quad 7$

2. Human Capital and Artificial Intelligence 8

3. Human Capital and Health 8

B. Physical Capital $\quad 8$

C. Natural Capital 10

D. Social Capital 12

V. DRIVING CHANGE THROUGH SYSTEMIC REFORMS 13

$\begin{array}{ll}\text { REFERENCES } & 17\end{array}$ 


\section{FIGURES}

Figure 1 Global Carbon Dioxide Emissions Pathways to Net Zero 5

Figure 2 The PRC's CO Emissions 1997-2017 6 


\section{ACKNOWLEDGMENTS}

We are grateful to Ehtisham Ahmad, Amar Bhattacharya, Benedict Bingham, Qi Ye, and Zou Ji for guidance. We recognize support from the Grantham Foundation, and the Economic and Social Research Council. Jennifer Sabourin and Yangsiyu Lu provided valuable editing and research assistance. 


\begin{abstract}
Over the last 40 years, major investments in physical and human capital yielded a dramatic 10-fold increase in per capita output in the People's Republic of China (PRC). Over the coming 40 years, major investments in natural and social capital, alongside strong but different further investments in physical and human capital could yield dramatic advances in well-being, quality, and sustainability, while maintaining steady, if lower, rates of growth of output.

Greater quality and quantity of investment in the four capitals can be delivered by a partnership of government and an innovative private sector. Wise investments in the different capitals are mutually supportive, achieving multiple goals simultaneously. For example, extensive, clean, and efficient public transport can enhance all four capitals and thus help deliver more inclusive, cleaner, and higher-quality well-being and economic growth.

Natural capital and social capital are already becoming central objectives of economic policy. The 14th Five-Year Plan provides a unique opportunity to fine-tune policy making to support the PRC's transition to high-quality development by determined investments in the four capitals, which will require a combination of private and public finance.
\end{abstract}

Keywords: People's Republic of China, 14th Five-Year Plan, economic development, physical, human, natural, and social capital 


\title{
ABBREVIATIONS
}

\author{
Al Artificial intelligence \\ BRI Belt and Road Initiative \\ $\mathrm{CO}_{2}$ Carbon dioxide emission \\ CSAs Climate-smart agricultural approaches \\ FYP Five-Year Plan \\ GDP Gross domestic product \\ IPCC Intergovernmental Panel on Climate Change \\ OECD Organisation for Economic Co-operation and Development \\ PRC People's Republic of China \\ PV Photo voltaic \\ SDG Sustainable Development Goal
}





\section{INTRODUCTION}

Over the last 40 years, major investments in physical and human capital yielded a dramatic 10-fold increase in per capita output in the People's Republic of China (PRC). Over the coming 40 years, major investments in natural and social capital, alongside strong but different further investments in physical and human capital could yield dramatic advances in well-being, quality, and sustainability, while maintaining steady, if lower, rates of growth of output.

Greater quality and quantity of investment in the four capitals can be delivered by a partnership of strong government and an innovative private sector. Wise investments in the different capitals are mutually supportive, achieving multiple goals simultaneously; for example, extensive, clean, and efficient public transport can enhance all four capitals and thus help deliver more inclusive, cleaner, and higher-quality well-being and growth.

Recognizing this, the 13th Five-Year Plan (FYP), 2016-2020 addressed the transition to high-quality development. The plan embedded the principles of the "ecological civilization" through reforms to tackle pollution, environmental damage, natural resource depletion, and climate change through energy conservation, emissions reduction, and low-carbon development initiatives. The plan highlighted the importance of inclusive development through goals to eliminate absolute poverty by 2020 and measures to reduce distributional imbalances and improve social services.

In 2017, the 19th Communist Party of China National Congress launched the New Era, a set of reforms to modernize the economy and achieve "advanced country" status by 2050. The 14th FYP, 2021-2025, is the starting point of this process. At the core, the New Era aims at accelerating the transition to high-quality development and improved living standards through increased productivity and resource efficiency coupled with investments in human capital and greater social inclusion and environmental protection.

Natural capital and social capital are already becoming central objectives of economic policy. The PRC has brought natural capital to center stage with its emphasis on the environment, its action against pollution, and its moves to curb greenhouse gas emissions toward net zero. The PRC recognizes the importance of social capital, a cohesive society, addressing inequality, and of acting to promote good governance.

Selective investments in the four capitals can foster this critical transformative process and will require a combination of private and public finance. The nature and combination of these finances will be a vital part of systemic reform. It will range from bank loans, angel investments and crowd funding for small enterprises, to capital markets for major private sector firms to raise debt and equity finance, to largescale finance, including development banks for large infrastructure projects. Sustainability and green finance can be an important part of this

The paper is structured as follows. The next section elaborates on the strategic reforms for the New Era to be framed in the 14th FYP. Section III sets out the core elements of the new growth story in a changing world, indicating key broad areas for investment, how they fit together, and the key policy areas and reforms that can bring those investments forward. Section IV provides a detailed analysis of the investments needed in the four forms of capital. The final section sets out the economy-wide reforms which can underpin the processes of transformation and growth described in the paper. 


\section{STRATEGIC REFORMS FOR A NEW ERA}

The PRC has transitioned from low-income to upper-middle-income status in the last 4 decades. ${ }^{1}$ This extraordinary achievement is the result of sequential and structured reforms, with each set of reforms tailored to the next phase of the country's development, taking into account lessons from the experience of earlier phases. The PRC has always looked ahead to chart the next stage of reforms as the economy and technology advance, challenges appear, and as the world changes. It will transform itself again in the next decades, when it will move to high-income status, but the dimensions of the transformation will change. Well-being, quality, and sustainability will be at center stage, moving away from the past emphasis on outcome and income. All past reforms have been of great importance, but such are the strengths of past lessons and the magnitude of changes on the global stage that this next set of reforms is of special significance, not only for the PRC but also for the world.

The late 1970s saw key reforms in agricultural and household institutions, the 1980s brought support for entrepreneurship, township and village enterprises, and special economic zones. In the 1990s, the financial sector was reformed with the growth of specialist banks and the creation of development banks, and in the 2000s the focus moved to human capital, with shifts in education and greater provision of social insurance. Throughout, there has been increasing emphasis on market mechanisms and on interaction with the world economy.

The growth story of the coming decades progresses beyond the standard economic models in which growth is shaped largely by physical capital. That approach was encapsulated in the Harrod-Domar idea that growth is the investment rate divided by the incremental capital-output ratio (Harrod, 1939; Domar, 1946). That was the 20th century growth story. The 21st century growth story will be based on balanced accumulation of several types of capital, on structural change toward the service sector, on higher quality outputs and inputs, and on labor and resource efficiency and productivity. These changes will in turn be driven in large measure by further institutional and market reforms.

These new forms of growth can and should be sustainable. Sustainability means offering to the next generation opportunities at least as good as those available to the current generation, assuming they behave in the same way toward those that follow. Sustainability thus depends on the quantity and quality of four types of capital central to well-being and wealth: human capital, social capital, physical capital, and natural capital (Stern, 2015, chapter 6.4; Hamilton and Hepburn, 2017; Managi and Kumar, 2018; Lange et al., 2018). Investing in and achieving high productivity of these capitals is crucial to enabling economic growth to continue at high rates with lower factor inputs, and to making growth sustainable. Sustainability of this coming process of growth is of fundamental importance not only for the PRC but also for the world.

The new growth strategy should also be inclusive, and it must embrace a world which is changing rapidly, with new technologies, particularly artificial intelligence (AI) and automation (Adams, 2018), with the challenges of climate change (IPCC, 2018), and with new threats to world trade. There will be disruptions and risks to be managed as well as great opportunities in innovation and investment.

The PRC has already begun an approach to growth, which embodies a focus on the quality and quantity of these four types of capital. For example, it has emphasized the importance of the ecological civilization (Naustdalslid, 2014); acted against air, water, and land pollution; increased forest cover; and is moving to curb greenhouse gas emissions. All of these involve taking care of, investing in, and avoiding the destruction

World Bank Classifications. 
of natural capital. Similarly, on social capital, the PRC has emphasized the importance of a cohesive society, has expressed concerns about inequality, and acted to promote good governance (Liu, 2017; Shigong, 2018). The PRC has invested, through health and education, in the human capital of its people.

Thus, while physical capital has been central in the past, recent years have seen a deepening understanding of the dangers for the other three forms of capital of poorly designed, low-quality, or polluting physical capital. Such capital can pollute soil and water and damage forests, in other words, reduce or destroy natural capital. Damage to natural capital can undermine human health, damaging or destroying human capital and undermining social capital.

Moving sustainability and these four forms of capital to center stage in the PRC's 14th FYP will be a natural evolution of the policy and planning direction that the PRC has recognized and taken forward in recent years. But the pressures from the past emphasis on accumulating physical capital, have made it vital that the emphasis on sustainability and the four forms of capital is strong and explicit in the 14th FYP. These pressures have motivated increased emphasis on the key elements of well-being as the economic and societal objectives, rather than the narrow goal of output or income, in alignment with the Sustainable Development Goals (SDGs) (United Nations Development Programme, 2015).

The approach to investment in multiple forms of capital can be structured in ways that are inclusive and reduce inequality. For example, a priority for extensive, clean, and efficient public transport will largely benefit lower income sections of the community, since they are more dependent on public transport, including in facilitating access to employment. Air and water pollution tend to affect disproportionally poorer people. Tackling these challenges with new clean technologies will reduce pollution and offer job opportunities (New Climate Economy, 2018).

In emphasizing the importance of the transition to the low-carbon economy and the growth and job opportunities it entails, we should recognize that the target within 30-50 years must be a net zerocarbon economy. Net zero is necessary to stabilize temperatures and must be achieved within 30 to 50 years if we are to stabilize "well below $2^{\circ} \mathrm{C}$." As the recent Intergovernmental Panel of Climate change (IPCC) report on $1.5^{\circ} \mathrm{C}$ has shown, the difference between $2^{\circ} \mathrm{C}$ and $1.5^{\circ} \mathrm{C}$ embodies real dangers (IPCC, 2018). The PRC is so large that if the world is to be at net zero, then so too will be the PRC. Achieving this requires an urgent review of all investments in long-lived fossil infrastructure that might outlast a 30-50-year time horizon (Pfeiffer et al, 2018).

The innovations and investments of the coming decade should largely be driven by the private sector. Private firms are a crucial source of the creativity and new ideas that higher quality, high-tech and sustainable growth require. That means that reforms should be market oriented. Sustainable infrastructure, well-functioning cities and good governance will be vital to support this. Public policy, public institutions and public investment should work to create an investment climate for the innovations and investments that are needed.

\section{HIGH-QUALITY AND SUSTAINABLE GROWTH IN A CHANGING WORLD}

The old approach to development is coming to an end for eight reasons: pressures on the environment; social strains, including inequality; changing technologies and the need for new skills; demographic challenges; rising wages; shift in demand toward services; changing world economic geography and 
interactions; pressures on public finances. The first four of these are issues of natural, social, and human capital. The last four concern processes of development which are associated with changes toward and through middle- and higher-income economies.

The pressures on environment are both local and global. The air of cities has been severely polluted. So too have soil and water. Climate change is an immense risk. We know that strong global action is urgently needed, and that the PRC, because of the size of its economy and emissions, must be a central player in climate action. The world economy will double in the next 2 decades and within that the PRC's economy will more than double. In the same period, global emissions will have to be cut by at least $25 \%$ (see Figure 1) to meet the Paris Agreement target of well below $2^{\circ} \mathrm{C}$. World infrastructure will likely double in around 15 years, much of it associated with urban expansions and a large part in the PRC. If this new additional world economy looks like the old one, cutting emissions absolutely by more than $25 \%$ would be impossible. Hence the need for radical and urgent change.

Inequality has been a pressing concern in the PRC for some time: urban-rural; regional, including in areas with declining industries; and across individuals. In the early stages of reform some rise in inequality was inevitable. But over the last 2 decades inequality has become a focus of attention. A rapidly aging population adds to the challenge.

The PRC's wages have risen as its economy has advanced, investment has increased, and workers have become more skilled. All this is part of success, but also requires new strategies for the future. The era of the PRC being the dominant world force in low-cost manufacturing is ending, at least at the simple end of manufacturing. Future technological change, with $\mathrm{Al}$ and robotics, is likely to transform investment, work, consumption, and the functioning of cities. It will stretch across all sectors, including services as well as manufacturing.

The pressures on natural capital and social capital that have been described imply that fostering a better environment and managing inequality and social cohesion should appear strongly in societal objectives. Both the environment and inequality are multidimensional challenges including air in cities, forests, rivers, and oceans in the former, and gender, generational, and regional in the latter. A rapidly changing world, the potential dislocation arising from new technologies, and pressures from an aging population all point to the importance of security. All these lead us to the centrality of sustainability in objectives.

The recognition that output is inadequate as the dominant objective is, of course, longstanding in the PRC and elsewhere. However, the experience of the last few decades has led us to be much more multi-dimensional, explicit, and analytical about the expression of objectives. The SDGs emerged from these discussions, and capture the key dimensions associated with the environment, inequalities, and opportunities. They include the functioning of cities, infrastructure, the state of oceans, climate, forests, and opportunities for rewarding employment and challenges of insecurity. They are a valuable framework for thinking about and setting societal objectives.

The 14th FYP will chart the course for the New Era. It must embrace the challenges and opportunities of new technologies, changing economic geography, and sustainability. It has to tackle the pressure on public finances stemming from urbanization, infrastructure, education health, social security, and changing demography. Investment and innovation in all forms of capital, human, physical, natural, and social should be at the core of the plan.

On technological and sectoral change, the PRC should now shift its balance toward higher-tech and services. This follows from rising wages, the rapid technological changes that are coming through, and demand patterns which move, as incomes rise, toward services. This will involve strong investment in 
research and development and innovation, and new skills. It will also require management of declining industries and locations. The speed of technological change and a slowing growth rate imply that changing balance in the economy can no longer occur simply by some sectors growing more rapidly than others. Social cohesion and economic justice require that such transitions are managed. There are many instruments which can and should be used, involving training, finance, the location of government activities, and social protection as discussed in the next section.

\section{Figure 1: Global Carbon Dioxide Emissions Pathways to Net Zero}

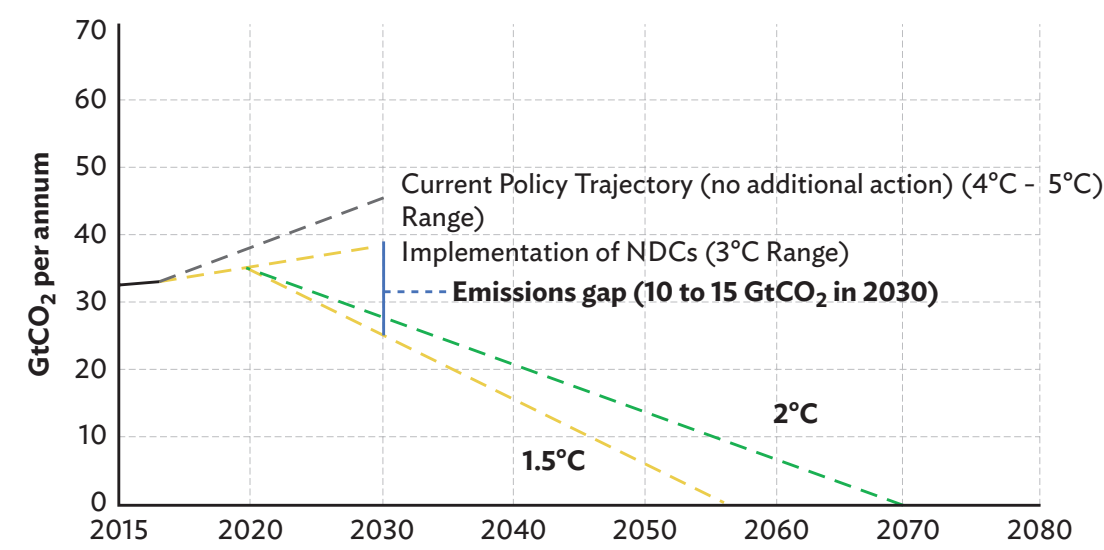

$\mathrm{CO}_{2}=$ carbon dioxide, $\mathrm{GtCO}_{2}=$ gigatonnes of carbon dioxide, $\mathrm{NDC}=$ nationally determined contributions.

Source: UNEP, 2017 and Le Quéré et al., 2018

In 30-50 years from now the world must have zero-net carbon emissions if we are to have a reasonable chance of achieving the Paris targets, as shown in Figure 1. Because of its size, this requires that the PRC must also be close to zero-carbon. This means that its emissions, which appear to be plateauing (Figure 2) as a result of impressive efforts toward efficiency and away from fossil fuels, should start to move down. The PRC's Paris nationally determined contributions involve peaking emissions by 2030. However, from the world aggregate requirements, if the Paris temperature targets are to be within reach, for emissions to fall by more than $25 \%$ in the next 20 years, this could not happen unless the PRC's emissions peak and start to fall strongly during the 14th FYP.

The key areas for investment and innovation will be in: new technologies that can give high-quality growth; modern service sectors, including health, education, transport, communications and IT, finance, and logistics; functioning of modern cities, including in their infrastructure and in relation to pollution, congestion, and efficiency; and food and land-use systems. Overall resource productivity and efficiency will be crucial and there is real potential in the idea of the circular economy with its emphasis on design for re-use and recycling. Resource efficiency and productivity are not only powerful forces for growth but also crucial elements for the protection of natural and human capital. Investments and innovations for the 14th FYP and on policies to foster the investments and changes will be examined in the next two sections of the paper. 
Figure 2: The PRC's CO $\mathrm{CO}_{2}$ Emissions 1997-2017*

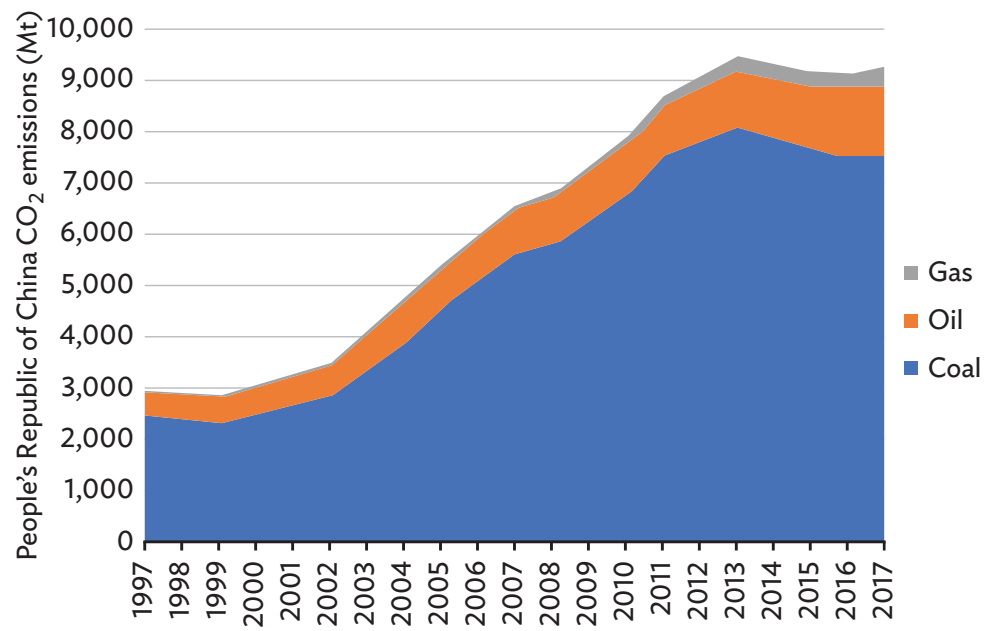

* $\mathrm{CO}_{2}$ emissions are estimated on data from the China Energy Statistical Yearbook (National Bureau of Statistics, 2016)

$\mathrm{CO}_{2}=$ carbon dioxide, $\mathrm{Mt}=$ megatonnes

Source: Mi, 2018.

Policy measures will involve further strengthening of the role of the market in the allocation of resources. For the markets to work well in guiding investment and innovation, governments must analyze and act on market failures. Key areas of potential market failure include: (i) greenhouse gas emissions and pollution; (ii) research and development; (iii) capital markets; (iv) networks and/or grids, public transport, broadband and/or information and communication technology; and ( $v$ ) information on opportunities, including technologies, in a changing world. All of these will support innovation and strong and sustainable investments. Further, government policies must have the predictability and institutional strength to provide the necessary confidence for investment. There may be increasing challenges in the PRC of monopolistic or oligopolistic positions in both public and private sectors, which could hinder innovation and growth.

One final point on the overall strategy involves the PRC's lessons for the world. The reform period of the last 4 decades has brought remarkable success in raising incomes and reducing poverty. It is unique in human history. But it has also brought stresses and problems. If the technologies of today had been available to the PRC 25 years ago, its development path might have been much cleaner and more sustainable, to the great benefit of its citizens. If it had been able to look ahead more clearly to the problems of congested and polluted cities, it might have made policy and investments differently. Many of the countries under the Belt and Road Initiative (BRI) are, in terms of income per capita, where the PRC was 2 decades ago. Thus, the PRC has a real opportunity to help BRI countries toward a more sustainable, more efficient, and greener form of development.

\section{INVESTING IN THE FOUR CAPITALS TO DELIVER HIGH-QUALITY SUSTAINABLE GROWTH: HUMAN, PHYSICAL, NATURAL, AND SOCIAL CAPITAL}

Investment in the four key capitals moves to center stage in the 14th FYP. The PRC has already begun to embrace an approach to growth and development, which embodies a focus on the quality and quantity of these four types of capital, as it reflects on its experience and deepens its understanding of 
well-being. Recent years have also seen increasing emphasis on, and deepening understanding of the close connections between these different capitals.

The dangers from low-quality physical capital to the other three capitals are evident; polluting physical capital damages natural capital, which undermines human health, reducing the productivity of human capital, which in turn can undermine social capital. Difficulties with social capital or human capital can also distort investment and lead to low-quality physical capital. All four capitals need to be considered, and with due care for the interactions between them, with a program of balanced investment in all. This section considers the four key capitals as part of such a balanced investment program.

\section{A. Human Capital}

The world is changing rapidly. There are major potential disruptions and risks to labor markets, as well as great opportunities, created by the need to respond to fundamental challenges, including climate change, $\mathrm{Al}$ and automation, the functioning of cities, and shifts in trade and investment. Major investments in sustainable infrastructure will be core to a response. The PRC can take the opportunities from these developments by investing in human capital to create a highly skilled, healthy, flexible labor force that is well adapted to the challenges and changes of the coming decades.

We highlight three dimensions of the investment in human capital for the New Era. First, the requirement for around $\$ 30$ trillion in infrastructure investment in the PRC alone by 2040 (Heathcote, 2017), before the investment needs in BRI countries are added, creates a huge potential demand for new skills, with appropriate training in relevant and clean technologies. Second, education and lifelong learning is now even more important in a rapidly changing and high-tech world. There will be real challenges in enabling humans to contribute productively alongside, rather than simply being directly replaced by machines. Third, human capital is most Al productive when workers are healthy. Public investment in health, to manage non-communicable diseases and pollution that currently kills millions of people annually can have a significant impact on human capital. We consider each dimension in turn.

\section{Human Capital and Sustainable Infrastructure}

The PRC will require substantial investment in sustainable infrastructure as it urbanizes and moves to higher-quality and sustainable growth. Such infrastructure will likely include high-voltage direct current interconnectors, charging points for electric vehicles, refueling for hydrogen trucks and ships, overhead wiring on major roads for long-distance electric trucks, further investment in solar photovoltaic power $(\mathrm{PV})$, and batteries, among other new, cleaner, and often higher-technology infrastructure. Large investments will be required in new forms of public transport and waste management. The associated jobs will require new training, skills, and management.

The skills that are required in the PRC will change as it moves up the value chain into more sophisticated and cleaner technologies. The PRC's management of the rapid changes in the labor markets will require investing in the re-training of current workers and the provision of continuing education. This will also be a part of delivering a "just transition" toward the new growth era (discussed further in section on social capital). The PRC has already been active in recognizing and managing these issues. For example, when construction was delayed or halted on 151 coal power plants, the PRC established a \$15 billion fund for retraining, reallocating, and early retirement of the estimated 5-6 million people who would be laid off due to coal or steel sector overcapacity (Wong, 2017). These approaches will be important to fostering human capital, maintaining social capital, and creating high-quality economic growth in the New Era, as discussed further below. 


\section{Human Capital and Artificial Intelligence}

Digital technologies and innovations, such as $\mathrm{Al}$, have the potential to radically increase efficiency and enable new business models across most sectors of the economy (Adams, 2018). A highly skilled labor force is necessary for firms to be able to successfully adopt such frontier technologies (Acemoglu and Zilibotti, 2001; Caselli and Coleman, 2006). Without suitable skills, the productivity of human capital will be lower, implying lower wages and lower standard of living for workers (Yi Che and Lei Zhang, 2017)

These Al-based technologies are far from maturity, and as they advance, the PRC has the opportunity to train its labor force to be effective, efficient, and agile in an increasingly automated world. The value of improvements in the quality of primary education is well-known (Zheng Wei and Rui Hao, 2011), and related findings are also emerging for higher education (Yi Che and Lei Zhang 2017). Complementary skills to Al-such as coding or other computing skills-might be significant elements in future productivity growth. With the automation of whole categories of tasks, greater value will be placed upon skills and talents that are different from and complementary to Al, such as those involved in human creativity or care.

\section{Human Capital and Health}

Health is a significant driver of the productivity of human capital, as well as a key element in well-being. Public investment in health entails powerful economic and social returns, particularly those in the areas of public health and prevention activities. Radically reducing pollution-strengthening natural capitalcan be a strong driver of improvement in health outcomes. It has been estimated that air pollution leads to about 1.2 million premature deaths annually in the PRC (Ritchie and Roser, 2018), and costs an estimated $3.5 \%$ of national gross domestic product (GDP) annually (Umbach and Yu, 2016). One third of Chinese households rely upon solid fuels for heating and cooking, with indoor air pollution leading to an estimated 600,000 deaths in the PRC each year (Roser and Ritchie, 2018). Changing cooking methods can increase social capital, raise productivity and enhance the quality of life. Women benefit significantly when access to more productive, and cleaner energy improves, including through the creation of more time for income-generating activities or childcare (both yielding higher productivity of human capital) or leisure (increasing well-being). These ideas and actions can be powerful agents of change.

Overall, the rapid and multidimensional changes in the global economy and technologies create opportunities for higher-quality economic growth in the PRC, built on higher-productivity human capital. Thus, central to success in the New Era will be a strong program of investment in human capital with education, training and public health at its core, delivering a highly skilled, flexible, healthy, and productive labor force that can rise to the many challenges and opportunities ahead.

\section{B. Physical Capital}

Physical capital underpins the functioning of modern societies. Physical capital includes infrastructure, buildings, machinery, among others (Hamilton and Hepburn, 2014). We focus here on infrastructure. Daily, infrastructure delivers comfort and well-being to its users in the form of reliable power networks, heating and cooling. It provides mobility through transport infrastructure. It also keeps citizens healthy by delivering clean water and sanitation. Infrastructure provides services that enable other activities to function. In short, infrastructure is at the heart of the achievement of sustainable development, including health, economic growth, and environment. It has significant positive effects on inequality and inclusivity, if done well. This sub-section sets out the importance of infrastructure for economic growth and development before illustrating the importance of sustainability for resilience of the economy, future society, and the planet. Sustainable infrastructure is at the core of the SDGs (see, for example, Bhattacharya et al., 2016). The sub-section concludes by stressing that a wise sustainable infrastructure investment strategy can also help shape the PRC's relationship with the world, notably through the BRI. 
Infrastructure can drive growth; calculations from the International Monetary Fund suggest that a $1 \%$ in infrastructure investments as a share of GDP can lead to a direct increase of $0.4 \%$ in annual economic growth (Abiad, Furceri, and Topalova, 2014). Taking into account indirect effects, the full impact is seen within 4 years, with additional growth in GDP potentially reaching $1.5 \%$ a year (Abiad, Furceri, and Topalova, 2014). Evidence suggests that returns generated on well-managed, carefully selected public investment projects are likely to significantly exceed their financing costs (International Monetary Fund 2015; Organisation for Economic Co-operation and Development [OECD], 2016 cited in Zhengelis, 2016). At the same time, careful planning and management are necessary for the positive effects to be realized (Banerjee et al., 2012; Ansar et al., 2016).

The world's infrastructure will likely double or more in the next 2 decades, with increasing world population, rising urbanization and income levels through which many emerging market and developing economies will be moving (Bhattacharya et al., 2016; New Climate Economy reports of 2014, 2015, 2018; Heathcote, 2017). Over half of global infrastructure needs lie in Asia. The PRC alone is expected to require in the region $\$ 30$ trillion in infrastructure investment by 2040 , comprising more than half of Asia's total needs and $30 \%$ of global (Heathcote, 2017).

Bhattacharya et al. (2016) and Kennedy and Corfee-Morlot (2013) argue that making infrastructure sustainable is not likely to cost much more but does require changing the way we invest. Investment into low-carbon energy technologies would need to grow by a factor of 10 over the period 2016-2050 (OECD/International Energy Agency, 2017, p.67) for growth to be compatible with the Paris $2^{\circ} \mathrm{C}$ objective. The levels of infrastructure investment required and the need to make such investment sustainable will require clear strategies, strong policies, and the right kind of finance, at the right time (see Bhattacharya et al., 2016, and New Climate Economy reports 2016 and 2018).

Infrastructure investments which are low-carbon and resilient have many benefits beyond the fundamental contributions of mitigation and adaptation in relation to climate change. Reliable, clean power networks reduce pollution and improve competitiveness. PV solar systems can be more efficient, resilient, and inclusive than conventional systems, particularly for isolated, low-density areas. Better urban public transport reduces congestion and air pollution, with large economic and health impacts, particularly for poor people. Upgrading industrial processes can significantly increase efficiency, reduce waste, and lower production costs, especially in transitioning and developing countries. The United Nations Industrial Development Organization has estimated that implementing best industrial technologies could reduce energy intensity worldwide by as much as $26 \%$ in the next 25 years, triggering a $32 \%$ reduction in global carbon dioxide $\left(\mathrm{CO}_{2}\right)$ emissions from the energy system (New Climate Economy, 2018). The PRC's experience demonstrates that improving energy efficiency in industries can deliver substantial savings: during the first 4 years of the 12th FYP energy productivity increased significantly across several key sectors delivering an estimated $\$ 18$ billion economy-wide annual energy cost savings (International Energy Agency, 2016).

The economic and social costs of investing in low-quality and old-fashioned infrastructure projects can be very high. Evidence in the PRC shows that investment, and especially overinvestment, in low-quality, low-productivity infrastructure can pose severe risks to economic and financial stability (Ansar et al., 2016). Experience has shown the dangers of consequences such as sovereign debt overhang, excessive monetary expansion and economic fragility (Ansar et al., 2016). Social and sustainable infrastructure investments require good policies, strong institutions, and appropriate financing. The role of sufficiently resourced local governments and the management of inter-temporal liabilities at provincial-level authorities is highlighted by Ahmad (forthcoming) and by Fan and Zhang (forthcoming).

With major impacts of climate change already materializing, the risks of damage to infrastructure through heavier and more frequent weather-related events will further increase. This can result in high costs in repairing and rebuilding. It can damage the financial health of companies and insurers, which in turn can 
have serious consequences for the financial system (TCFD, 2016; Scott et al, 2017). Rapidly declining costs of clean alternatives to fossil-fuel energy sources and increasingly stringent climate and energy policies across the globe, intensify the risks of economic dislocation and 'stranded assets' (Campiglio et al., 2018). Lewis (2014) estimates that implementation of policies for a $2^{\circ} \mathrm{C}$ scenario could cause the fossil-fuel industry to lose of the order of $\$ 30$ trillion in revenues over 2 decades.

Failing to implement such policies would place future generations in grave danger. Continuing with investment in infrastructure, which is based largely on fossil fuels for another decade or two could lockin emissions, and take us beyond $3^{\circ} \mathrm{C}$. The effects to lives and livelihoods would be devastating, with consequences of severity for the poorest.

Many Chinese and international energy analysts argue that the PRC's coal consumption cannot be realistically replaced fully by gas, renewables, and nuclear power before 2040 . However, this is far from concluding that a net zero emissions scenario is impossible within 30 to 50 years. The Government of the PRC aims to raise its non-fossil fuels share to $15 \%$ of the national energy mix by 2020 . The PRC has already successfully invested in solar PV power: according to the PRC's National Energy Administration, by the end of 2016, the total installed capacity of PV power generation in the PRC reached 77 gigawatts. The PRC has become the world's largest producer of solar cells surpassing Europe and Japan (Shuai et al. 2018). Shuai et al. (2018) urge that the PRC should continue supporting the solar PV industry, and encouraging more technological innovation to further enhance the international competitiveness of its products. This is an opportunity for the PRC to accelerate investment in the infrastructure of the future, and to create economic resilience and a healthier, cleaner and more productive and sustainable economy.

This investment strategy can also shape the country's relationship with the world. The PRC's trade and investment strategy for the New Era, with higher technology and services internally and more low-cost manufacturing externally, is clearly interwoven with the BRI. The PRC's partnerships with BRI countries will be of fundamental importance to both the PRC and the world. Connectivity is vital for fostering trade; so, too, is productive capacity elsewhere. A wider and more decentralized set of strategic partnerships will lead to more resilience for the Chinese economy as well as providing the strong productivity gains that trade can offer.

\section{Natural Capital}

Natural capital comprises the resources provided to us by nature, including renewable resources, such as forests, fisheries, functioning ecosystems, and a stable climate. These deliver vital services. Natural capital also includes exhaustible resources, such as coal, oil, and gas. While traditionally economists have been concerned about the depletion of exhaustible resources, it is increasingly recognized that most such resources are in plentiful supply, with good institutions, and can be well-managed by markets and the price system (Hepburn, Pfeiffer and Teytelboym, 2017). In contrast, renewable natural capital is often poorly managed, with underinvestment leading to damages to ecosystems, loss of species, excessive pollution, and premature deaths, reducing overall productivity and well-being.

Much of natural capital can be natural infrastructure, in the sense that it provides services, which allow other activities to function. Forests shape watersheds and avoid landslides. They provide tourism facilities, medicines, and biodiversity. Mangroves protect against coastal erosion and storm surges.

Successful investment in and protection of natural capital involves clear national and community strategies, so that impacts are understood, their wider economic and systemic effects are evaluated, and appropriate choices can be made. This is recognized by the PRC's leadership: at PRC President Xi Jinping 19th Party Conference Speech (2017) there were more references to "environment" and "green" (89 times) than the "economy" (70 times). Of the 14 elements in President Xi Jinping's speech, three relate directly to sustainability. 
The PRC has implemented many successful reforms to improve public health and environment (Huang, 2018). The smog in its cities has begun to be tackled by switching to natural gas from coal and via air management systems. Longer-term measures include investment in new public transport. The PRC is targeting 5 million electric cars on its roads by 2020. These efforts are beginning to yield results, with air quality in 338 cities across seeing a 6.5\% improvement from 2016 (New Climate Economy, 2018). The PRC's emissions appear to be stabilizing (see Figure 2) and energy intensity has reduced by $24 \%$ in the past 5 years.

Ebenstein (2012) finds that industrial activity has led to a severe deterioration in water quality in the PRC's lakes and rivers and estimates that a deterioration of water quality by a single grade (on a six-grade scale) increases the digestive cancer death rate by $9.7 \%$. Currie et al. (2013) provide both direct and indirect evidence that the coal-based winter heating strategy cut life expectancy by over 5 years in the northern region during the period 1981 to 2000.

On a global scale, the atmosphere constitutes natural capital of the most fundamental importance. Our greenhouse gas (GHG) emissions play a vital role in its future. It is in shaped by the functioning of our forests, land-use, and oceans, which constitute vital elements of natural capital. We see today the intensity of effects arising from past mismanagement. The last 20 years have seen 19 of the warmest years on record. Disasters triggered by weather and climate-related hazards were responsible for $\$ 320$ billion in losses in 2017 (New Climate Economy, 2018).

The reduction of $\mathrm{CO}_{2}$ emissions is core to the world's natural capital. As shown in Figure 2, the growth of the PRC's emissions decelerated during the time of the 12th FYP (2011-2015) and plateaued during the 13th FYP (2016-2020). We have argued that they could begin to fall during the 14th FYP, to the great benefit of the PRC and the world. Net zero emissions in the next 30 to 50 years may seem implausible to some, given the current structure of the Chinese economy, but the PRC's remarkable economic achievements over the last 40 years would have seemed implausible to an observer in 1978. The incentives and rewards to 3 or 4 future decades of rapid reform may be even larger than in the past.

Further, there are great potential local health benefits from policies which encourage switching away from fossil fuels. For example, it is estimated that phasing in a $\$ 70$ carbon price in the PRC could prevent nearly 4 million premature deaths from air pollution up to 2030 (Parry et al. 2016).

Much natural capital is affected by agricultural practices. The PRC can develop climate-smart agricultural approaches (CSAs) to increase agricultural productivity sustainably, raising the quality of life and public health, and protecting the environment. CSAs cover new production systems, including landscape farming approaches, intercropping, and integrated crop-livestock management; and improved water, soil, and nutrient management. They contribute to food safety. Effective CSA practices can produce higher productivity, create better jobs and income for farmers, and mitigate climate change. They can be more resilient to difficult weather. Crop diversification and agroforestry have been shown to increase yields while avoiding environmental impacts (New Climate Economy, 2018).

Finally, improved strategies for future urbanization could play an important role in the protection of natural capital and the enhancement of other forms of capital. It is estimated that globally compact, connected, and coordinated cities could provide up to $\$ 17$ trillion in economic savings by 2050 , stimulate economic growth by improving access to jobs and housing, while also strengthening resilience to physical climate risks and delivering up to 3.7 gigatons per year of $\mathrm{CO}_{2}$ savings over the next 15 years (World Resources Institute, 2017).

Unlocking the power of cities to deliver clean economic development is not merely about pricing reforms and fostering new markets, but requires planning of compact, connected, and coordinated use of urban land. The PRC alone could reduce infrastructure spending by up to $\$ 1.4$ trillion by pursuing more 
compact, connected urban growth (World Bank, 2014). Functionally and socially mixed neighborhoods with access to green spaces, comfortable, affordable, and climate-smart housing for all, and efficient public transport networks could both protect natural capital and provide a basis for higher quality, stronger, and more sustainable economic growth.

\section{Social Capital}

As explored above, the world is changing rapidly and creating major disruptions and potential risks to employment and labor markets. The PRC can anticipate and prepare for these changes by investing in human capital to create a highly skilled, healthy, and flexible labor force that is well equipped for the challenges of the coming decades. The impacts of these changes together with shifting demographic trends require careful attention to social, as well as human, capital. Definitions of social capital vary but the concept refers to the ties within a society that facilitate cooperation within or among groups (OECD, 2009). In this paper, we highlight the key elements of social cohesion, trust, and sound institutions. In the following, we briefly outline some of the pressing challenges related to social capital and ways of responding to them, stressing the importance of transition strategies for the management of structural and social change, social safety nets, and sound institutions.

The PRC has emphasized the importance of a cohesive society and expressed concerns about inequality (Liu, 2017). Absolute poverty has reduced dramatically over the last 4 decades and evidence on consumption by poorer households indicates that the remaining poor people are making strong progress toward climbing out of extreme poverty ( Li and Pontes, 2018). However, there exists a large income gap between urban and rural populations ( $\mathrm{Li}$ and Pontes, 2018). The PRC's policymakers have highlighted the importance they attach to closing this gap, including the provision of equal access to good education and health services.

Moving up value chains, shifting toward the service sector, and adopting cleaner ways of producing, have all started to affect the PRC's society, as well as its economy. Managing the phase-down of high-carbon industries and the millions of workers they employ, and to accelerate transitions within - or away fromthe communities in which these industries are concentrated presents an important challenge. This is a universal challenge for all countries, but in the PRC, it is particularly pronounced due to the sheer size of its high-carbon and heavy industrial sectors. However, it is just one part of a bigger story. Demand shifts toward services as economies get richer and their comparative advantage changes, a process that has moved very rapidly in the PRC. And there is strong labor-saving technical progress already occurring and much more is on the way. The management of the low-carbon transition should be set in the context of these continuing transitions (Averchenkova et al., 2016, Neuweg \& Averchenkova, 2017), as we discuss briefly below and further in Section IV.

The consequences of these transitions are often concentrated regions where entire communities can be affected (Beatty, Fothergill, and Powell, 2007). Their way of life is often closely intertwined with an industry that employs a large share of the local population. This is particularly relevant for mining communities (Beatty, Fothergill, and Powell, 2007). The effects on those communities often extend beyond concerns about economic means to support livelihoods. Scott (2010), for example, illustrates, through an ethnography of mountain top removal mining in Appalachia, the various social and communal ways in which attachments are formed through identity, place, and working-class masculinity.

A strategy of reducing inequality and eliminating poverty in the PRC would have several elements. First, train for life-long learning. Second, when old activities fade, make particular efforts to provide re-training. Government revenues from environmental tax reform could be used for lowering labor taxes, and funding education, vocational training, and re-skilling programs. Third, provide assistance and finance for local entrepreneurship in starting or expanding small and medium sized-enterprises. Fourth, provide help to 
move for those who wish to move, through information, finance and relaxing the hukou system. Fifth, provide social safety nets designed, as far as possible, to help reintegration into work or provide support or pensions for those who are unable to do so. In all this, active dialogue between local communities, employees, employers, and local government will greatly facilitate design that fits local circumstances and the reality and a sense of being involved.

The ability of the PRC to absorb future liabilities of an aging population-pensions, elderly care, and health-is a pressing concern (Ansar et al., 2016). The drivers of the aging population, its consequences, and potential ways of alleviating them are explored in detail by Lee and Zeng (forthcoming). Social and human capital are interwoven. Reforms of the intergovernmental fiscal system (Ahmad, forthcoming) and wise and transparent spending decisions, including on infrastructure, can help manage or reduce income disparities. Sound, sustainable, and inclusive local systems for funding public investment can foster social cohesion, trust, and strong institutions.

\section{DRIVING CHANGE THROUGH SYSTEMIC REFORMS}

We have described earlier the reasons why the PRC's current phase of development and reform is coming to an end and a new era of growth and development is beginning. The new growth path will embody higher quality, cleaner, more efficient, and more sustainable consumption and production; more inclusive and cohesive economies and societies; and lead toward a stronger "ecological civilization" with economic activities more in harmony with the natural environment.

All of this will require innovation and investment in the four types of capital; human, physical, natural, and social. In the preceding section we described investments in all four, how we could avoid growth in one form of capital (particularly physical capital) undermining the quantity and the quality of others, and some relevant policies in each case. In this concluding section we describe some economy-wide reforms which foster and promote the new growth strategy. While we discuss elements of the systemic reform package separately, the reforms we set out are complementary and interwoven. Taken together, they provide an advance in the conditions for private investment, in public investment, in institutions and in the role of state, toward a Chinese model of institutions and policies for the passage to a high-income country, ecological civilization, and a harmonious and cohesive society.

We examine seven areas in turn: price, regulation, and enterprise reform; financing investment in the four forms of capital; public finance; the functioning of cities; internal governance including the quality of institutions; the management of radical change and dislocation; and global governance of trade, the international financial institutions, and the global commons.

First, rapid and efficient change toward growth which embodies high-quality, high-tech, greater services and sustainability will require strong and clear price signals. If private sector investment and innovation are to be fostered within a strong and sound investment climate, then both price signals and regulation should take account of the potential market failures discussed in Section II. An example would be a strong carbon price, and thus it is important to make sure the new carbon markets work well. This could include possible consideration of carbon price floors and carbon taxes. But carbon prices do not by themselves re-design cities, reduce congestion, or promote compactness. Nor do they by themselves ensure that products, systems and buildings are designed in a way that the components can be re-used or recycled. These key features will require in addition direct public action for the design and reform of cities, including regulation and standards. Further, reform is also likely required for state-owned enterprises so 
that they are not sites of inefficiency or kept alive artificially when their activities or methods of work are obsolete. That works against resource productivity and sustainability and can make eventual adjustment costs more severe, as noted by Fan and Zhang (forthcoming). The PRC will be dependent on creativity and entrepreneurship in the New Era and a clear, sound, transparent, and supportive investment climate is crucial.

Second, investment in all four forms of capital will require a combination of private and public finance. The nature and combination of these finances will be a vital part of systemic reform. It will range from bank loans, angel investments, and crowd funding for small enterprises, to capital markets for major private sector firms to raise debt and equity finance, to large-scale finance, including development banks for large infrastructure projects. Sustainability and green finance can be an important part of this. So too will be major mortgage, insurance, and pension institutions as households buy houses and plan for old age.

Transparency, sound banking standards and regulation of individual institutions and the system will be of increasing importance in the financial sector. As the sophistication of the economy and financial system grows, the danger of financial crises increases. Crises cannot be wholly avoided but their probability, intensity, and impact can be reduced by sound investment decisions, coherent policy, and strong institutions. Investment, and especially overinvestment, in unproductive infrastructure carry severe risks to economic and financial stability. This can be alleviated by careful assessment of infrastructure costs, their financing structure, and the actual benefits they generate. Sound, sustainable investment criteria can be strengthened, and their use mandated. Their wide-spread application could help avoid the problem of "building more" instead of "building right". Wise regulation is of great importance, both avoiding the problems of excessive risk-taking and of the potential distortions and risk of directed credit.

Third, the public finances can also be a source of instability and crisis. The PRC has managed the national public finances responsibly over the years, but serious problems could emerge, and arguably have emerged, at lower levels particularly in cities. Cities will be the focus of most of the investments, particularly infrastructure investments, of the New Era. They have most of the population and output, pollution and greenhouse gas emissions. Their relative importance will grow. Hence how they are managed in physical, human, social, environmental, and financial terms will be critical to the PRC's future.

Fourth, and interwoven with public finances, for cities to create a stable investment climate and to carry through the infrastructure and other investments necessary to function in a clean, efficient, and sustainable way, their public finances must be managed well. To do this this, strong revenue streams from local taxation, and payments for services are needed. Local taxation can take several forms including taxation of land and property, pollution or carbon taxes, and local additions to income tax, among other measures. It is important that these taxation powers are clear and well-executed and are not contradictory or confusing relative to taxation from national authorities. Transparency and efficiency of local taxation, as well as expenditures, will be crucial to delivery of the next stages of the PRC's development.

The functioning of cities constitutes a major part of the investment climate but good governance, our fifth issue, particularly in relation to investment, goes beyond cities. Private investment is at the heart of the growth model of the New Era and it is very sensitive to the quality of governance, as well as the quality of infrastructure services. The quality of governance has a profound influence on how easy it is to get things done and the confidence of the investor in the returns to investment.

We can identify three elements of the quality of governance in relation to investment: the soundness of policies; the predictability of policies; and the functioning and behavior of institutions. We have already discussed in the paper the meaning of sound policy in the New Era, particularly in regard to getting markets to give better signals, by overcoming market failure. Predictability reduces government-induced policy risk. Such risk is a major deterrent to investment around the world. We do, of course, learn over time about new possibilities; new evidence appears; experience teaches lessons. But if investor uncertainty 
is to be managed the criteria for policy change must be understood, and, as far as possible, be set out in advance. Government policy should be "predictably flexible".

Another source of both cost and uncertainty lies with the functioning and behaviors of institutions. Sometimes institutions and officials can be bureaucratically heavy or obstructive. And sometimes they are corrupt. The more licenses and permissions that are required, the greater the likelihood that these problems or obstacles can arise. In creating a good investment climate, it is important that bad or unnecessary intervention is reduced. That does not mean, of course, abandoning regulation and standards, for example, on pollution or safety. The argument here is that government should focus on the important and make the application of the regulation and standards as user-friendly as possible.

Sixth, major change inevitably involves some dislocation. Such issues arise more strongly as the PRC is now an established producer in many sectors. Some of these sectors will contract, such as coal mining, steel, and some of low-cost manufacturing. The impact might be large in specific geographical locations. This type of change, if badly managed, can damage social cohesion and create lack of hope or a sense of injustice.

Seventh, our final subject on systemic reform concerns global governance. As the world's second largest economy the PRC is a major influence on the world stage, even though its per capita income is still lower than many high-income countries. Thus, it is not only acting on the world stage, it also, inevitably, shapes that stage. What happens to world trade and investment, to the global commons and to the future of the international financial institutions is of vital importance for the PRC and the world. On all these, the world, including the PRC, will benefit greatly from a well-functioning, rules-based, and equitable world order.

On trade and investment, the extraordinary growth and development of the last 70 years has demonstrated the great benefits of collaborative and open international systems. Since such systems began in the late 1940s, global output per head has gone up by a factor of 4 and global life expectancy has increased by around 30 years, from around 40 to 70 years. This has been a unique period for development in world history. It is vital that these international systems are maintained and enhanced (Stern, 2018, Fulbright lecture).

The PRC has a crucial role to play. Moving from a world with one dominant power, the United States (US), to a bipolar world with the US and the PRC in tension or antagonism would be damaging. It is unsurprising, therefore, that we see public discussion of the Thucydides Trap (see for example, Allison 2017). An open and international order with all countries participating will be more productive than a system dominated by quarreling between two major powers. An open, rules-based order would allow us to tackle more effectively the problems of the 21 st century while continuing to lift people out of poverty.

The challenges of the global commons, particularly climate change, are of great urgency, as we have argued. The PRC played a leading role in creating the Paris Agreement in 2015. The PRC has begun to stabilize its emissions. It will likely begin to reduce them in the 14th FYP. The PRC is now, inevitably, in the vanguard of action and international collaboration on climate change. There are great opportunities for the PRC, not only in terms of its own new model of growth and its technological advances but also in terms of global leadership.

Finally, the world's international institutions, the United Nations, the International Monetary Fund, the World Bank, the regional development banks, and the World Trade Organization, will increasingly look to the PRC for leadership. The PRC's role in the G20 will be crucial-its presidency in 2015 and the Hangzhou Summit were an important example. As the report of the G20 Eminent Persons Group (October 2018) argued, the International Monetary Fund is in urgent need of more resources if future financial crises are to be better managed and their frequency is to be reduced. The multilateral development banks could 
be still more effective if they functioned as a group. That would involve the creation of country platforms for better co-ordination of action in support of a country's development program. The PRC, which is increasingly important as a supporter of development in other countries, could play an important role here.

This brief discussion of systemic reforms has covered: policy and sustainable infrastructure to create an investment climate to foster private sector innovation and investment; strengthening of the financial system for strong, productive, and stable financing; better functioning cities, including their public finances; and local governance and global governance. Together, these systemic reforms could foster the investments in physical, human, national, and social capital which will drive forward the PRC's New Era of high-quality, sustainable, and inclusive growth and development. 


\section{REFERENCES}

Abiad, A., D. Furceri, and P. Topalova. 2014. The Time Is Right for an Infrastructure Push. World Economic Outlook 2014. Washington DC: International Monetary Fund.

Adams, A. (2018). Technology and the labour market: the assessment. Oxford Review of Economic Policy, 34(3): 349-361.

Allisson, G. (2017). Destined for War: Can America and China Escape Thucydides's Trap? Houghton Mifflin, New York.

Acemoglu, D. and Zilibotti, F. (2001). Productivity Differences. The Quarterly Journal of Economics. 116(2): 563-606.

Ahmad, E., Neuweg, I. and Stern, N. (forthcoming). Growth, Structural Transformation, and the New Global Agenda: What this means for China and the World. In Fouquet, R., Ed. Handbook on Green Growth. Edward Elgar Publications. Cheltenham, UK, and Northampton, MA, United States.

Ahmad, E. (forthcoming). Financing High Quality Development. ADB East Asia Working Paper Series. Asian Development Bank. Manila

Ansar, A., et al. (2016). Does infrastructure investment lead to economic growth or economic fragility? Evidence from China. Oxford Review of Economic Policy 32(3): 360-390.

Averchenkova, A. et al. (2016). Climate policy in the United States, China and the European Union: Main Drivers and Prospects for the Future: In-depth country analysis. Policy Paper. Grantham Research Institute.

Banerjee, A., et al. (2012). On the Road: Access to Transportation Infrastructure and Economic Growth in China. NBER Working Papers 17897. National Bureau of Economic Research.

Beatty, C., et al. (2007). Twenty years on: has the economy of the coalfields recovered? Environment and Planning A, 39(7): 1654-1675. IDDRI, 2018. Implementing Coal Transition - Insights from case studies of major coal-consuming economies. Available at: https:/www.iddri.org/en/publications-and-events/ report/implementing-coal-transition-insights-case-studies-major-coal.

Bhattacharya et al. (2016). Delivering on Sustainable Infrastructure for Better Development and Better Climate. The Brookings Institution, New Climate Economy, Grantham Research Institute on Climate Change and the Environment, Washington DC.

Campaglio, E., et al. (2018) Climate Change Challenges for Central Banks and Financial Regulators. Nature Climate Change, 8(6): 462-468.

Caselli, F. and Coleman II, W.J (2006) The World Technology Frontier. American Economic Review 96(3): 499-522.

Che, Y. and Zhang, L. (2017). Human Capital, technology adoption and firm performance: impacts of China's education expansion in the late 1990s. The Economic Journal 128 (614): 2282-2320.

Currie, J., et al. (2013) What Do We Know about short term and Long Term Effect of Early Life Exposure to Pollution? National Bureau of Economic Research Working Paper No. 19571. 
Domar, Evsey (1946). "Capital Expansion, Rate of Growth, and Employment". Econometrica. 14 (2): 137 147. doi:10.2307/1905364. JSTOR 1905364.

Ebenstein, A. (2012). The consequences of industrialization: evidence from water pollution and digestive cancers in China. The review of Economics and Statistics. 94(1): 186-201

Eggleston, K., et al. (2013). 'Will Demographic Change Slow China's Rise?'. Journal of Asian Studies 72(03): 505-18.

Fan, G. and X. Zhang (forthcoming). Towards High Quality Development in the PRC. ADB East Asia Working Paper Series. Asian Development Bank. Manila

G20 Eminent Persons Group on Global Financial Governance (2018). Making the Global Financial System Work for All. Report of the G20 Eminent Persons Group on Global Financial Governance, October.

Hamilton, K. and Hepburn, C (2017). National Wealth: What is Missing, Why it Matters. Oxford University Press: Oxford.

Hamilton, K. and Hepburn. C. (2014). Wealth. Oxford Review of Economic Policy. 30(1):1- 20.

Harrod, R. F. (1939). "An Essay in Dynamic Theory". The Economic Journal. 49 (193): 14-33.

He, L. (2018). World Economic Forum. https://www.weforum.org/agenda/2018/01/pursue-high-qualitydevelopment-work-together-for-global-economic-prosperity-and-stability/

Heathcote, C. (2017). Forecasting infrastructure investment needs for 50 countries, 7 sectors through 2040 in World Bank Group, Infrastructure and Public-Private Partnerships Blog. 08.10.17. Accessed 25.10.18 URL: http://blogs.worldbank.org/ppps/forecasting-infrastructure-investment-needs-50countries-7-sectors-through-2040

Hepburn, C., Pfeiffer, A. and Teytelboym, A. (2017). 'Green Growth' in Clark, G., Feldman, M. P., Gertler, M. S., and Wojcik, D. The New Oxford Handbook of Economic Geography, Oxford: Oxford University Press.

Huang, $\mathrm{H}$ et al. (2018) Health impact of China's Air Pollution and Control Action Plan: An Analysis of national air quality monitoring and mortality data. Lancet Planetary Health, 2 (7): 313- 323.

IEA, 2016. Energy Efficiency Market Report 2016. IEA, Paris. Available at: https://www.iea.org/eemr16/files/ medium-term-energy-efficiency-2016_WEB.PDF

IPCC (2018). Global Warming of $1.5^{\circ} \mathrm{C}$ : An IPCC special report on the impacts of global warming of $1.5^{\circ} \mathrm{C}$ above pre-industrial levels and related global greenhouse gas emission pathways, in the context of strengthening the global response to the threat of climate change, sustainable development, and efforts to eradicate poverty. http://ipcc.ch/report/sr15/

Kennedy, C., \& Corfee-Morlot, J., 2013. Past performance and future needs for low carbon climate resilient infrastructure- An investment perspective. Energy Policy 59, p.773-783.

Lagarde, A., et al. (2016). Climate policy in the United States, China and the European Union: Main Drivers and Prospects for the Future: In-depth country analysis. Policy Paper. Grantham Research Institute. 
Lange, G. M., et al. (2018). The Changing Wealth of Nations 2018: Building a Sustainable Future. Washington, DC: World Bank. https://openknowledge.worldbank.org/handle/10986/29001 License: CC BY 3.0 IGO.

Lee, R. and Zeng, Y. (forthcoming). Population Aging in China: Responding to Long Run Challenges. ADB East Asia Working Paper Series. Asian Development Bank. Manila

Lewis, M. (2014). Stranded assets, fossilised revenues. ESG Sustainability Report. Kepler Cheuvreux. 24 April 2014. Available at: www.keplercheuvreux.com/pdf/research/EG_EG_253208.pdf.

Li and Pontes (2018). https:/www.worldbank.org/en/news/press-release/2018/02/22/promoting-amore-inclusive-and-sustainable-development-for-the PRC.

Liu, X. (2017). Speech by Ambassador Liu Xiaoming at the British Parliament: New Era for China and New Chapter of the China - UK Cooperation, House of Commons, 21 November 2017. Accessed 25.10.18. URL: http://www.chinese-embassy.org.uk/eng/tpxw/t1512703.htm

Managi, S and Kumar, P (2018). Inclusive Wealth Report: Measuring Towards Sustainability. 1 $^{\text {st }}$ Edition. Routledge.

Ming, C. (2015). Transcend Left and Right, Unite the Three Traditions, Renew the Party-State: A Confucian Interpretation of the China Dream.

Naustdalslid, J. (2014). Circular Economy in China - the environmental dimension of the harmonious society. International Journal of Sustainable Development \& World Ecology, 21 (4), 2014. Pp. 303- 313.

New Climate Economy (2018). Unlocking the Inclusive Growth Story of the 21 ${ }^{\text {st }}$ Century: Accelerating Climate Action in Urgent Times. The Global Commission on the Economy and Climate.

Neuweg, I. and Averchenkova, A. (2017). Climate legislation in China, the European Union and the United States. In: Averchenkova, A., Fankhauser, S., and Nachmany, M. eds. The Political Economics of Climate Change Legislation. London: Elgar Publishing.

OECD \& International Energy Agency [IEA], 2017. Chapter 2 of Perspectives for the energy transition - investment needs for a low-carbon energy system. Paris: OECD/IEA. Available at: https://www. energiewende2017.com/wp-content/uploads/2017/03/Perspectives-for-the-Energy-Transition_ WEB.pdf

OECD (2009), What is Human Capital? 28.10.2009. Accessed 24.10.2018. URL: http://www. migration4development.org/en/content/oecd-insights-human-capital-what-social-capital

Parry, I., et al. (2016). Climate Change Mitigation in China: Which Policies are Most Effective? IMF. Unlocking the Inclusive Growth Story of the $21^{\text {st }}$ Century: Accelerating Climate Action in Urgent Times. New Climate Economy: The Global Commission on the Economy and Climate pp. 47.

Pfeiffer A., et al. (2018). Committed emissions from existing and planned power plants and asset stranding required to meet the Paris Agreement. Environmental Research Letters 13054019

Ritchie, H. and Roser, M. (2018). "Air Pollution". Published online at OurWorldlnData.org. Retrieved from: 'https://ourworldindata.org/air-pollution' [Online Resource]. 
Roser, M. and Ritchie, H. (2018). "Indoor Air Pollution". Published online at OurWorldlnData.org. Retrieved from: 'https://ourworldindata.org/indoor-air-pollution' [Online Resource].

Scott, M., et al. (2017). The Bank of England's response to climate change. Topical Article. Quarterly Bulletin 2017 Q2. London, England: The Bank of England. Available at: http://www.unepfi.org/psi/wp-content/ uploads/2017/06/BANKOFENGLAND_response_climatechange.pdf

Scott, R.R. (2010). Removing Mountains: Extracting Nature and Identity in the Appalachian Coalfields University of Minnesota Press. United States.

Sen, A. (1999). Development as Freedom. Oxford University Press: Oxford UK.

Shigong, J. (2018.) Jiang Shigong on 'Philosophy and history: interpreting the "Xi Jinping Era' through Xi's report to the nineteenth national congress of the CCP'. Australian Centre on China in the WorldGuangzhou Journal Open Times.

Shuai, J., et.al. (2018) Are China's solar PV products competitive in the context of the belt and road initiative? Energy Policy 120 (c): 559-568.

Stern, N., Dethier, J-J. and Rogers, F.H. (2005). Growth and empowerment: making development happen. MIT Press: Cambridge MA.

Stern, N. (2015). Why are we waiting? The logic, urgency and promise of tackling climate change. MIT Press. United States.

Stern, N. (2018). The best of centuries or the worst of centuries: leadership, governance and cohesion in an interdependent world. The Eighth Annual Fulbright Lecture, June 2018. Published by the US-UK Fulbright Commission and Pembroke College Oxford, November 2018 (forthcoming).

The Economist (2018). Opening the gates. Chinese travellers of all sorts have become ubiquitous. Special Report China in the World.

Umbach, F. and Yu, K. (2016). China's Expanding Overseas Coal Industry: New Strategic Opportunities, Commercial Risks, Climate Challenges and Geopolitical Implications. EUCERS.

United Nations Development Programme (2015). 'World Leaders Adopt Sustainable Development Goals',25.9.2015.(accessed: 24. 10.18) http://www.undp.org/content/undp/en/home/presscenter/ pressreleases/2015/09/24/undp-welcomes-adoption-of-sustainable-development-goals-by-worldleaders.html

Wei, Z. and Hao, R. (2011). The role of human capital in China's total factor productivity growth: a cross -province analysis. The Developing Economies 49(1): 1-35.

Whiteford, Harvey A et al. (2010) Global burden of disease attributable to mental and substance use disorders: findings from the Global Burden of Disease Study, The Lancet, 382 (9904), pp. 1575 - 1586.

Wong, S.L. (2017). In China's rustbelt towns, displaced coal, steel workers lose hope and voice. Reuters, London. In Unlocking the Inclusive Growth Story of the $21^{\text {st }}$ Century: Accelerating Climate Action in Urgent Times. New Climate Economy, The Global Commission on the Economy and Climate pp.29.

World Bank (2014). Urban China: Toward efficient, inclusive, and sustainable urbanisation and supporting II. World Bank, Washington DC. 
World Bank (2017). Putting clean cooking on the front burner. World Bank, Washington DC.

World Economic Forum (2016). Global Challenge Insight Report. The Future of Jobs. http://www3.weforum. org/docs/WEF_Future_of_Jobs.pdf

World Resources Institute (2017). CAIT emissions data. Climate Watch. Washington DC. www. climatewatchdata.org.

Yu, J. (2018). The belt and road initiative: domestic interests, bureaucratic politics and the EU-China Relation. Asia Europe 16(3): 223-236.

Yu, S. and Lu, H. (2018). Relationship between urbanization and pollutant emissions in transboundary river basins under the strategy of the Belt and Road Initiative. Chemosphere 203: 11-20.

Yuhong, D. et al. (2017). Nonlinear effects of human capital on TFP: Evidence from eight ASEAN countries. Economic Cooperation \& Development. 38(4): 123-153.

Zenghelis, D., 2016. Building 21st century sustainable infrastructure: Time to invest. Policy Brief. London, England: Grantham Research Institute on Climate Change and the Environment. Available from: http:// www.Ise.ac.uk/GranthamInstitute/publication/building-21st-century-sustainableinfrastructure-part-1time-to-invest/.

Zhang, S. (2016). Fiscal decentralisation, budgetary transparency, and local government size in the PRC. Emerging Markets Finance and Trade 52(7): 1679-1697.

Zhang, T. (2016). Tea leaf nation, China's coming ideological wars. Foreign Policy 1 March.

Zhang, Q. \& Chan, J.L. (2013). New development: fiscal transparency in China - government policy and the role of social media. Public Money \& Management 33(1):71-75.

Zheng, S., Sun, C., Qi, Y. \& Kahn, M.E. (2014). The evolving geography of the PRC's Industrial production: implications for pollution dynamics and urban quality of Life. Journal of Economic Surveys 28(4): 709-724. 


\section{Driving Investments Toward Sustainable Economic Growth in the People's Republic of China}

Over the last 40 years, substantial investments in physical and human capital yielded the People's Republic of China (PRC) an impressive 10-fold increase in per capita output. In 2021, the PRC's 14th Five-Year Plan will initiate "New Era" reforms to modernize the economy and achieve advanced country status by 2050. This paper analyzes the human, natural, physical, and social capital investments necessary for the country to achieve higher quality, more sustainable economic growth and improved living standards. It also identifies the supporting policies and complementary reforms that will help the PRC create its new growth story.

\section{About the Asian Development Bank}

ADB is committed to achieving a prosperous, inclusive, resilient, and sustainable Asia and the Pacific, while sustaining its efforts to eradicate extreme poverty. Established in 1966, it is owned by 68 members — 49 from the region. Its main instruments for helping its developing member countries are policy dialogue, loans, equity investments, guarantees, grants, and technical assistance. 